\title{
Recoil Following Wiktor Stent Implantation for Restenotic Lesions of Coronary Arteries
}

\author{
Peter de Jaegere, MD, Patrick W. Serruys, MD, Gerrit-Anne van Es, PhD, Michel Bertrand, MD, \\ Volker Wiegand, MD, Jean Francois Marquis, MD, Matthias Vrolicx, MD, Jan Piessens, MD, \\ Bernard Valeix, MD, Gisbert Kober, MD, Wolfgand Rutsch, MD, and Rainer Uebis, MD
}

The purpose of this study was to determine acute recoil of the vessel wall immediately after Wiktor stent implantation in native coronary arteries of 77 consecutive patients and to assess whether there was compression or "late recoil" of the stent itself at long-term follow-up. Furthermore, the relationship between recoil and a number of clinical, angiographic, and procedural variables was studied in addition to the relation between acute recoil renarrowing or restenosis was assessed. All angiograms were analyzed with the Cardiovascular Angiography Analysis System using automated edge detection. Acute recoil was defined by the difference between the mean diameter of the fully expanded balloon on which the stent was mounted and the mean diameter of the stented segment. Late recoil was calculated by comparing the mean diameter of the stent itself immediately after implantation and at follow-up without opacification of the vessel.

Acute recoil amounted to $0.25 \pm 0.32 \mathrm{~mm}$ or $8.2 \%$. Multivariate analysis identified sex (coefficient $=-0.20, p=0.04$ ) and stent/artery ratio (coefficient $=0.99, p=0.0001$ ) as the only independent predictors of acute recoll. "Late recoil" of the stent itself was not observed. The overall difference between the mean diameter of the stent itself immediately after implantation and at follow-up was $-0.15 \pm 0.33 \mathrm{~mm}$, suggesting an overall increase in diameter of $5.0 \%$. There was no relation between acute recoil and late restenosis. On the contrary, there was a trend towards a greater degree of recoil in patients without restenosis. Moreover, linear regression analysis disclosed a weak but negative correlation between acute recoil and a loss in minimal luminal diameter (coefficient: $-0.55, p=0.04$ ).

The Wiktor stent effectively scaffolds the instrumented vessel. Only a minimal amount of acute recoil was noted, which did not contribute to late luminal renarrowing or restenosis. In addition, no late compression of the stent itself was observed. These data suggest that tissue ingrowth into the lumen of the stented segment is the main cause of late luminal renarrowing after stent implantation. (c) 1994 Wiley-Liss, Inc.

Key words: Wiktor stent, tissue ingrowth, lumen

\section{INTRODUCTION}

The precise mechanisms by which balloon angioplasty leads to luminal enlargement and clinical improvement remain unclear [1]. Several mechanisms have been proposed but rely principally on histopathological examination of experimentally induced atherosclerosis in animals or postmortem examination of human coronary arteries and therefore preclude any firm conclusions [2-7]. In vivo serial analysis of the vascular wall during balloon angioplasty with intravascular ultrasound has shown that in addition to plastic changes such as plaque fracture and compression, elastic changes occur that contribute to luminal enlargement $[1,8-10]$. As a response to these elastic changes, recoil may occur and constitute a mechanical reason for loss of gain achieved during balloon angioplasty [11]. Elastic recoil has been reported to ac-
From the Catheterization Laboratory and Laboratory for Quantitative Angiographic Analysis (Cardialysis), Thoraxcenter, Rotterdam, Netherlands; Département de Cardiologie, Hôpital Cardiologique, Lille, France; Department of Cardiology, Georg August Universität Göttingen, Germany; Department of Cardiology University of Ottawa Heart Institute, Canada; Department of Cardiology, University Hospital Gasthuisberg, Leuven, Belgium; Département de Cardiologie, Clinique la Casamance, Marseille, France; Department of Cardiology, Klinikum der J.W. Goethe Universität Frankfurt, Germany; Department of Cardiology Klinikum Charlottenburg Berlin, Germany; Department of Cardiology Medical Clinic I RWTH Aachen, Germany.

Received August 30, 1993; revision accepted December 13, 1993.

Address reprint requests to Peter P. de Jaegere, M.D., Catheterization Laboratory, Thoraxcenter, Dr Molewaterplein 40, 3015 GD Rotterdam, Netherlands. 


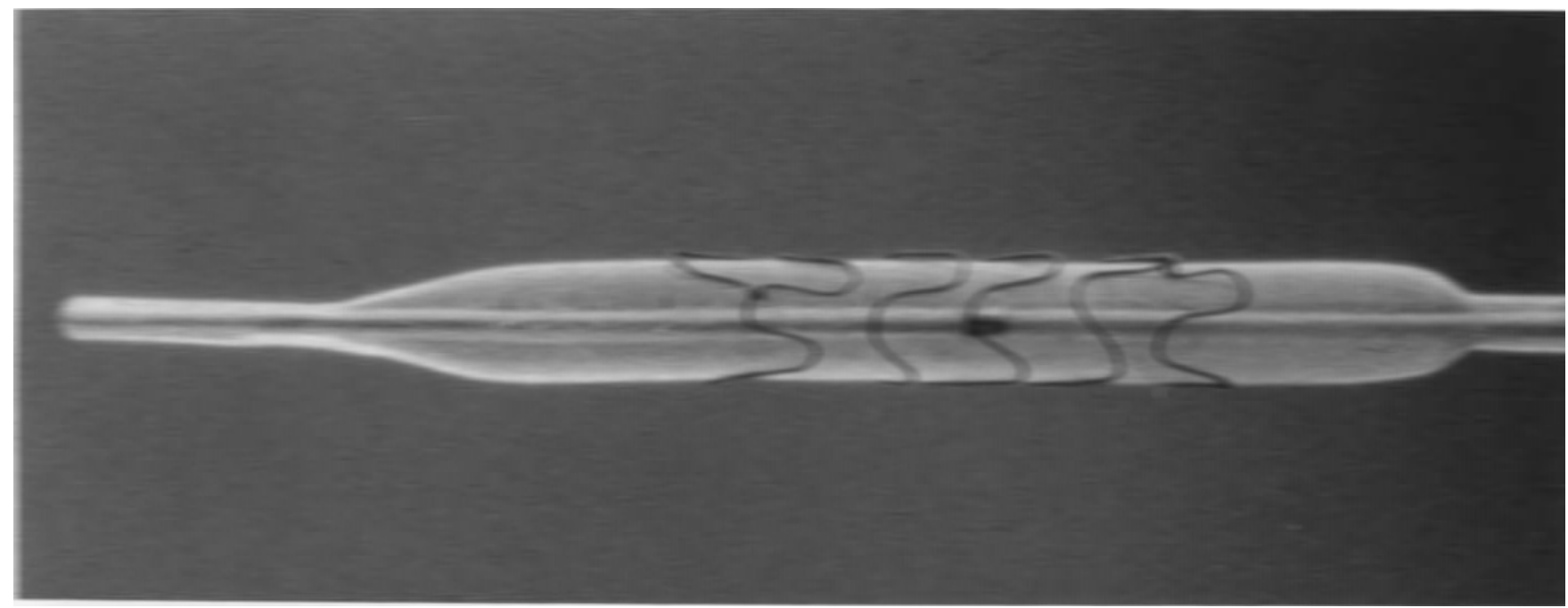

Fig. 1. The Wiktor stent is a radiopaque balloon expandable device, constructed of a single loose interdigitating tantalum wire $(0.125 \mathrm{~mm}$ in diameter) that formed into a sinusoidal wave and wrapped into a helical coil structure. The stent is crimped onto the deflated polyethylene balloon of a standard angio- plasty catheter. The features are such that by inflating the balloon the diameter of the stent increases without any alteration in length $(14-16 \mathrm{~mm})$. The crimped stent profile is approximately $1.5 \mathrm{~mm}$. count for an average $32-47 \%$ loss of the maximal achievable vessel diameter or vessel cross-sectional area [12-16]. To improve the immediate and long-term results of balloon angioplasty, intracoronary stent implantation has been advocated [17]. At present, the stent is the only catheter technology that scaffolds the vessel and therefore may prevent recoil. A number of stents are currently available [17-21]. They differ in geometry, wire thickness and physicochemical characteristics. It has been hypothesized that the Wiktor stent, which is constructed of a single loose interdigitating tantalum wire, may have less scaffolding properties compared to the other stents, which have a more rigid and stiff mesh architecture. Therefore, the purpose of this study was to determine elastic recoil immediately after Wiktor stent implantation in native coronary arteries and to assess whether there is compression or "late recoil" of the stent itself at follow-up.

\section{METHODS}

\section{Patients}

The study population consisted of 77 consecutive patients (88\% male, age $58 \pm 9$ years) in whom a single Wiktor stent (Fig. 1) was successfully implanted and in whom repeat angiography was performed at (mean \pm SD) $5.7 \pm 1.3$ months. In all patients, a stent was implanted because of recurrence of angina with objective evidence of ischemic due to restenosis of a lesion in a native coronary artery. A first restenosis was docu- mented in 44 patients $(57 \%)$, a second in 27 patients $(35 \%)$, and a third in 6 patients $(8 \%)$. The target vessel was the left anterior descending artery in 42 patients (54\%), the circumflex artery in 9 patients (12\%), and the right coronary artery in 26 patients (34\%). The nominal size of the stent used was (mean $\pm S D$ ): $3.40 \pm 0.37 \mathrm{~mm}$ (3.0-mm device in 30 patients $(39 \%), 3.5-\mathrm{mm}$ device in 33 patients $(43 \%)$, and a $4.0-\mathrm{mm}$ device in 14 patients (19\%). The baseline angiographic characteristics of the study population are shown in Table I. Written informed consent was required for every patient. The study protocol was approved by the ethics committee of the individual hospitals. The procedure of stent implantation and anticoagulation protocol have been described in depth elsewhere [22].

\section{Assessment of Recoil}

All coronary angiograms were analyzed by the computer-assisted Cardiovascular Angiography Analysis System (CAAS) using automated edge detection as previously described (23). Single identical views before and after stent implantation and during complete expansion of the balloon on which the stent was mounted were chosen for quantitative analysis. The same $\mathrm{X}$-ray setting in terms of kilovoltage and milliamperes were used during the cine recordings. Vessel segments were analyzed in the least foreshortened projection that is, perpendicular to the incoming X-ray beam. To dilate the vessel maximally and to control vasomotion, the same amount of intracoronary nitrates - either nitroglycerin, $0.1-0.3$ 
TABLE I. Baseline Angiographic Data of the 77 Study Patients*

\begin{tabular}{lc}
\hline Characteristics & Stent size \\
\hline Reference diameter $(\mathrm{mm})$ & $2.88 \pm 0.55$ \\
Minimal luminal diameter $(\mathrm{mm})$ & $1.14 \pm 0.37$ \\
Diameter stenosis $(\%)$ & $60 \pm 10$ \\
Reference area $\left(\mathrm{mm}^{2}\right)$ & $6.68 \pm 2.36$ \\
Minimal luminal cross-sectional area $\left(\mathrm{mm}^{2}\right)$ & $1.13 \pm 0.85$ \\
Area stenosis $(\%)$ & $82 \pm 11$ \\
Lesion length $(\mathrm{mm})$ & $12.6 \pm 2.33$ \\
Plaque area $\left(\mathrm{mm}^{2}\right)$ & $13.8 \pm 5.00$ \\
Symmetry & $0.50 \pm 0.30$ \\
\hline
\end{tabular}

*All parameters are expressed as mean $\pm \mathrm{SD}$.

$\mathrm{mg}$, or isosorbide dinitrate, $1-3 \mathrm{mg}$-was administered both before and after stent implantation [24].

\section{Definition of Recoil}

Elastic recoil immediately after stent implantation (acute recoil) was defined by the difference between the mean diameter of the fully expanded balloon on which the stent was mounted and the mean diameter of the stented segment immediately after stent deployment (Fig. 2). The time interval between balloon inflation and post-stent cine recordings was usually $<1 \mathrm{~min}$. To determine whether there was compression of the stent itself at follow-up (late recoil), advantage was taken of the unique radiopaque properties of the Wiktor stent. Automated edge detection was used to measure the mean diameter of the stent itself without opacification of the vessel. Late recoil was defined by the difference between the mean stent diameter immediately after implantation and at follow-up (Fig. 3).

A number of clinical (gender and age), angiographic (target vessel, vessel size, minimal luminal diameter before and after intervention, percentage diameter stenosis, lesion length, plaque area, symmetry, curvature), and procedural variables (stent/artery ratio defined as the ratio of the mean diameter of the fully expanded balloon on which the stent was mounted and the interpolated reference diameter) were selected to study their relationship with acute and chronic recoil.

Furthermore, the relationship between acute recoil and late restenosis was analyzed. For this purpose, recoil was not only defined by the definition described above, but also as the difference between the mean diameter of the final balloon diameter and the minimal luminal diameter post stenting. This was done because restenosis is classically described by the loss in minimal luminal diameter (difference between the minimal luminal diameter postintervention and the minimal luminal diameter at followup). In addition, the incidence of restenosis was defined according to the categorical approach using the $0.72-\mathrm{mm}$ and the $50 \%$ diameter stenosis criteria [19].

\section{Statistical Analysis}

The data are presented as mean $\pm \mathrm{SD}$. The $95 \%$ confidence intervals were calculated with the statistical package CIA [25]. When using an univariate analysis, continuous variables were divided in three subgroups of nearly equal size. Subgroups from categorical or discrete variables, or obtained from continuous variables were compared by means of the estimated differences and their $95 \%$ confidence interval.

To obtain independent predictors of recoil, variables were entered in a multiple linear regression analysis in which recoil was the dependent variable. Multiple linear regression analysis was performed to assess the relationship between the variables that were statistically significant at an 0.05 level in the univariate analysis (independent variables $\mathrm{X}_{1}$ ) and recoil (dependent variable $\mathrm{Y}$ ):

$$
Y=\beta_{0}+\beta_{1} X_{1},
$$

where $\beta_{0}$ is the intercept and $\beta_{1}$ the regression coefficient. The standard criteria of the $F$ statistic, whether significant or not, at a 0.10 level were used for inclusion and elimination in the model, respectively. Continuous variables were entered as such in the multivariate analysis, except for variables with two of three tertiles showing approximately the same amount of recoil. These were entered as discrete variables [26]. For every parameter retained in the final model, its estimated coefficient (i.e.. slope) and $p$-value are given. Regression analysis was carried out with a commercial statistical package (SAS-release 6.03).

\section{RESULTS \\ Acute Recoil}

The mean diameter of the fully expanded balloon and stented segment was $3.05 \pm 0.37 \mathrm{~mm}$ and $2.80 \pm 0.44$ $\mathrm{mm}$, repectively (Table II). Therefore acute recoil amounted to $0.25 \pm 0.32 \mathrm{~mm}$ or $8.2 \%$. Univariate analysis identified sex, reference diameter, lesion length and stent/artery ratio as potential predictors of acute recoil (Table III). After multivariate analysis, only sex (coefficient $=-0.20, p=0.04)$ and stent/artery ratio (coefficient $=0.99, p=0.0001)$ prevailed as the two independent predictors of acute recoil (Fig. 4).

\section{"Late Recoil"}

Late compression of the stent itself was not observed. On the contrary, the overall difference of the mean diameter of the stent itself immediately after implantation and at follow-up was $-0.15 \pm 0.33 \mathrm{~mm}$, suggesting an overall increase in diameter of $5.0 \%$ (Table IV). Lesion length and mean diameter of the stent immediately after 

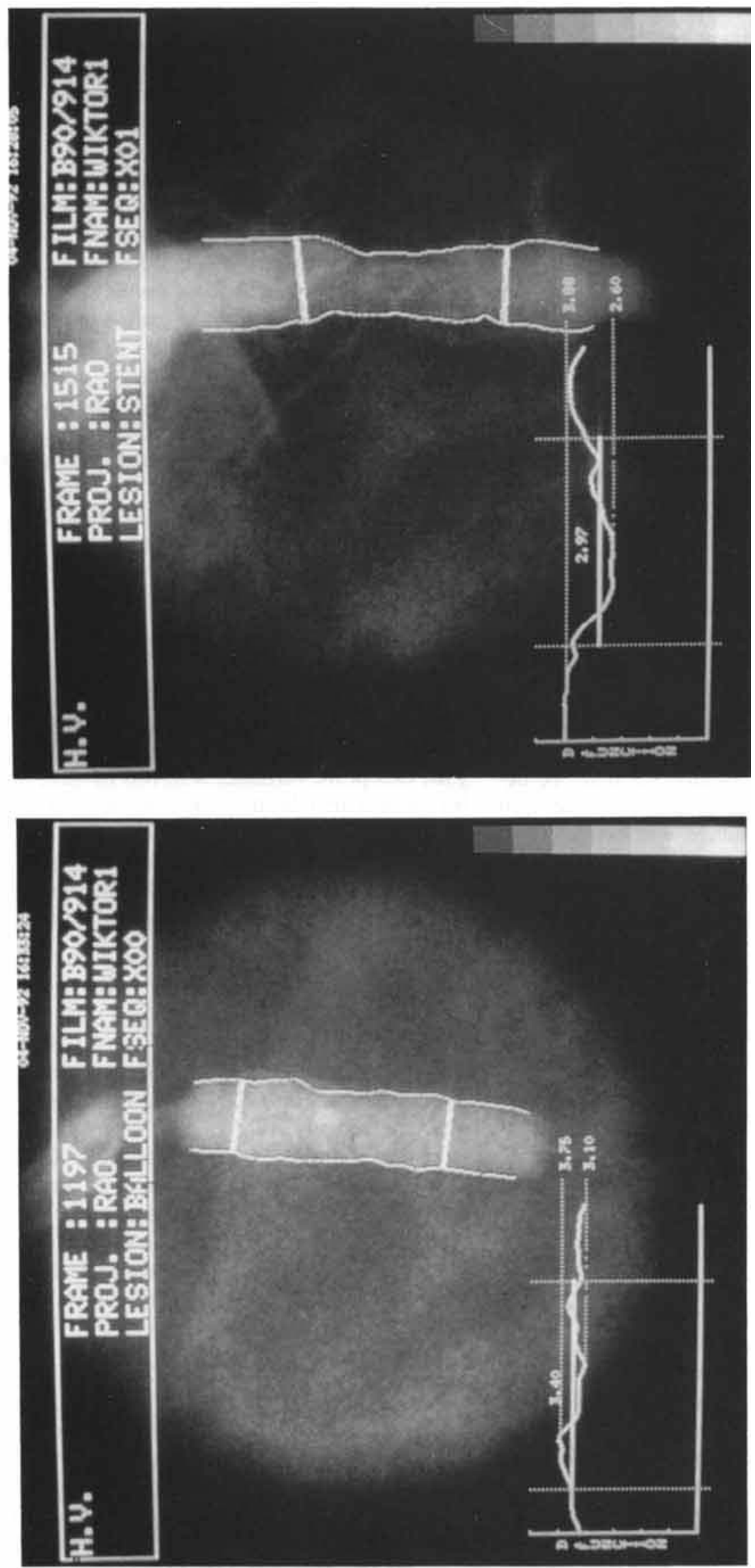

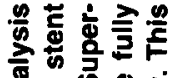
安的哭 조을 응 훙등 퉝 훌 \&

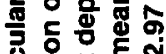
은

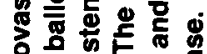
뭏 可 행ㅎㅀ

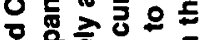
这这

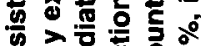

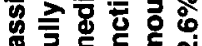
론 क्ष 을 혀웛 응 해용 政 웜 3 बक 웅 क्षे 혀을

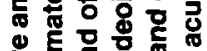

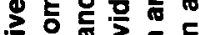

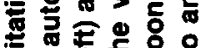
무원 글 등

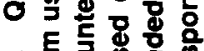
人

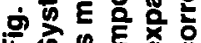
论 की.․ㅡ 틍 


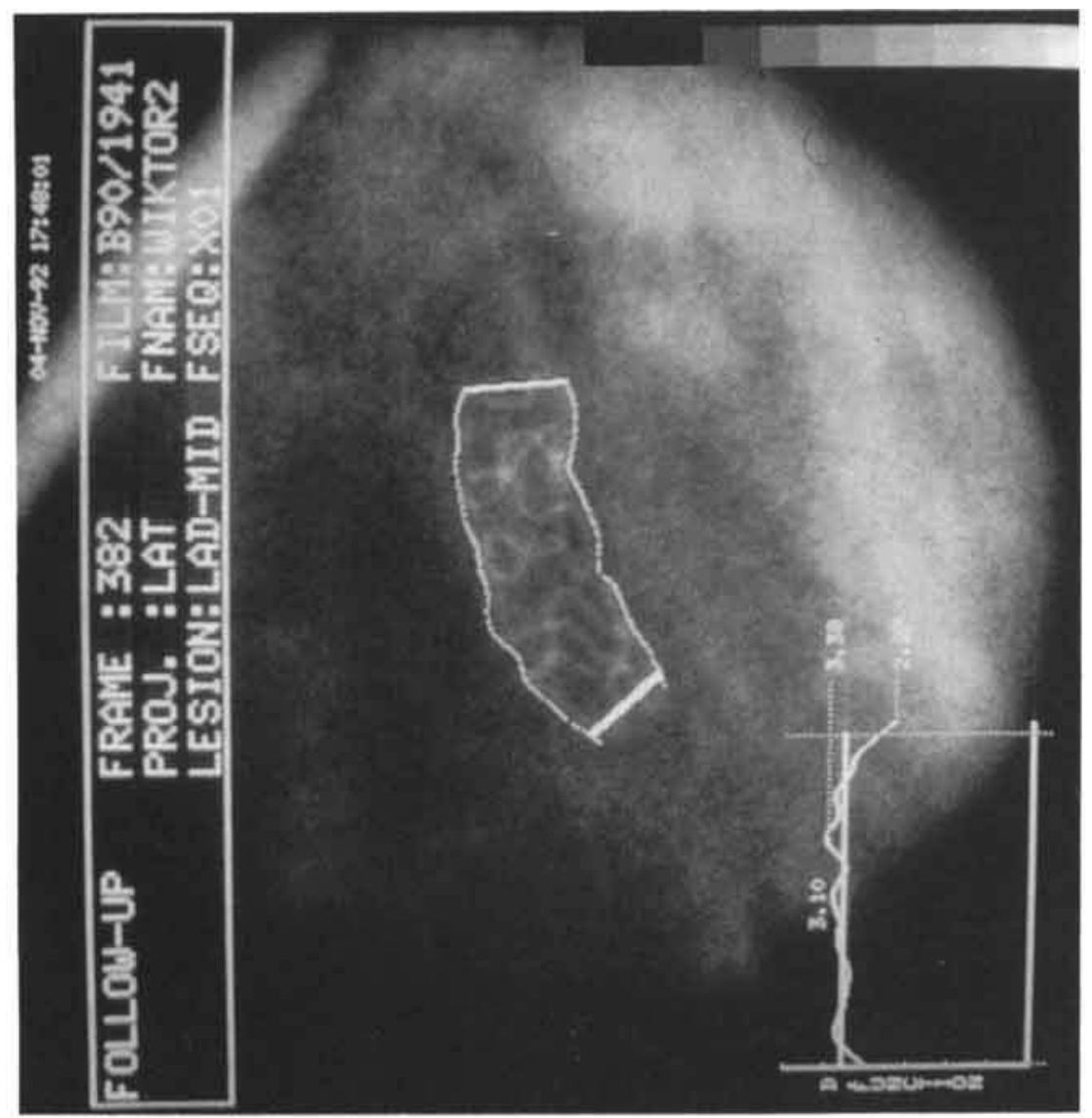

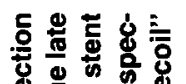

这

\%

영흐응

(4)

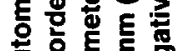

矛. 홍 훙

능 을

के

运野

范

\&

可

응형 类

잉

응 응 등

要

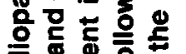

혼

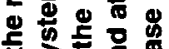

के के 등

홍 宊 o

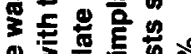
解 I웡 동

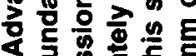
定. 门品 흥

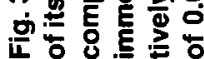

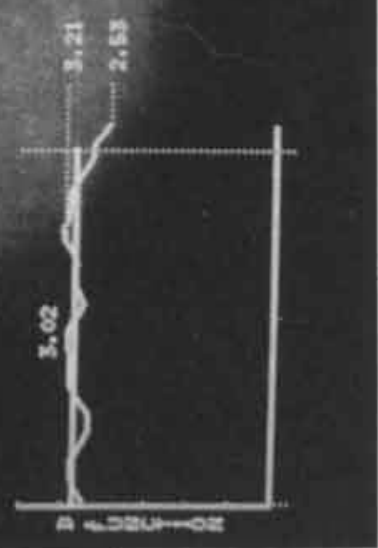


TABLE II. Acute Recoil Following Wiktor Stent Implantation in Native Coronary Arteries*

\begin{tabular}{llcc}
$\begin{array}{l}\text { Mean diameter } \\
\text { fully expanded } \\
\text { balloon }\end{array}$ & $\begin{array}{l}\text { Mean diameter } \\
\text { stented segment }\end{array}$ & Difference & $95 \% \mathrm{CI}$ \\
\hline $3.05 \pm 0.37 \mathrm{~mm}$ & $2.80 \pm 0.44 \mathrm{~mm}$ & $0.25 \pm 0.32 \mathrm{~mm}$ & $(0.18 ; 0.33 \mathrm{~mm})$
\end{tabular}

*All variables are expressed as mean $\pm \mathrm{SD} ; \mathrm{CI}=$ confidence interval.

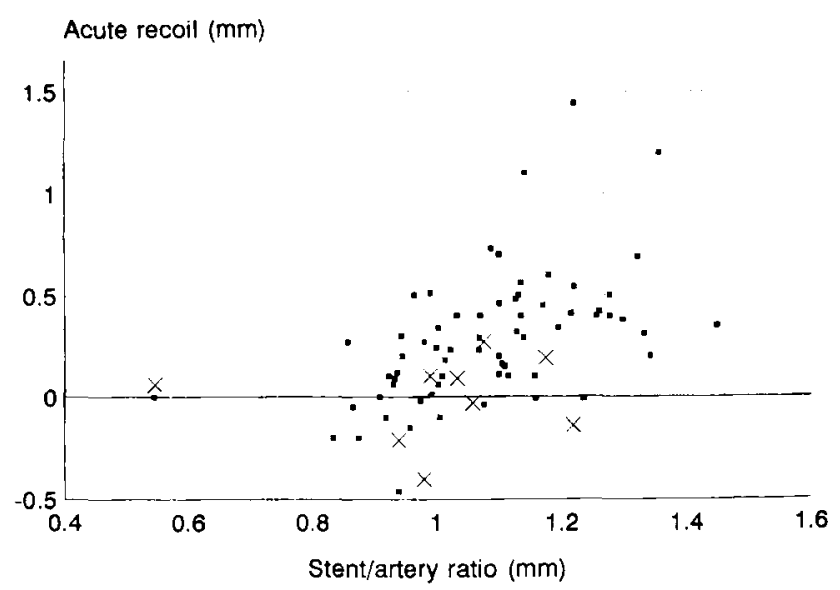

Fig. 4. Graphic display of the linear regression analysis studying the relationship between acute recoil ( $Y$-axis) and stent/artery ratio (X-axis). Stent oversizing is associated with significant more recoil. Dots denotes data of male patients; crosses denotes data of female patients.

implantation were identified as predictors of late recoil in the univariate analysis. They were both retained as independent discrete predictors in the multivariate analysis. Their corresponding coefficient and $p$-value were $0.16(p=0.04)$ and $0.28(p=0.0007)$, respectively.

\section{Relationship Between Acute Recoil and Late Restenosis}

The incidence of restenosis was $43 \%$ and $27 \%$, according to the $0.72-\mathrm{mm}$ and $50 \%$ diameter stenosis criteria, respectively (Table V). Irrespective of the definition of acute recoil described above, there was no difference in the degree of recoil between patients with restenosis and those without angiographic restenosis (Table $\mathrm{V}$ ). When defining recoil as the difference between the mean final balloon diameter and the minimal luminal diameter post-stenting (acute recoil 2. Table V), there was a trend towards a greater degree of recoil in patients without restenosis compared to those with restenosis according to the $0.72-\mathrm{mm}$ criterion $(0.70 \pm 0.30 \mathrm{~mm}$ versus $0.58 \pm 0.27 \mathrm{~mm}$, respectively). In addition, linear regression analysis disclosed a weak but negative correlation between acute recoil and loss in minimal luminal diameter (coefficient; $-0.55, p=0.04$ ). This trend toward an inverse relationship indicates that patients with more acute recoil tended to have a smaller loss in minimal luminal diameter. There was no relationship between acute recoil and minimal luminal diameter at follow-up (coefficient: $-0.004, p=0.99$ ).

\section{DISCUSSION}

Although the precise mechanisms by which balloon angioplasty lead to luminal enlargement are still incompletely understood, there is now substantial evidence that, in addition to plastic changes (e.g., plaque fracture, plaque compression, dissection), elastic changes (arterial wall stretching) occur that contribute to the dilatation process $[1,8,9,11]$. As a response to these elastic changes, elastic recoil after balloon angioplasty has been reported to be responsible for $32-47 \%$ loss of the theoretically achievable result, which in turn may affect the long-term angiographic outcome [12-16]. Since it has been hypothesized that the Wiktor stent may offer less scaffolding properties in comparison with other stents, the behavior of the vessel wall after Wiktor stent implantation and of the stent itself at follow-up were studied using quantitative coronary angiography.

In comparison with historical data on balloon angioplasty, only a limited amount of recoil $(0.25 \mathrm{~mm}$ or $8.2 \%$ ) was found [12-16]. This is in accordance with the degree of recoil observed after Wiktor stent implantation in non-atherogenic porcine coronary arteries [27]. Furthermore, these data, compare favorably with those of other investigators assessing recoil after stent implantation in human coronary arteries $[28-30]$. In these studies, recoil is reported to vary between 3.5 and $17.7 \%$ following Palmaz-Schatz stent implantation and between 20 and $22 \%$ following Gianturco-Roubin and Wiktor stent implantation [28-30]. The difference in recoil after Wiktor stent implantation between the study reported by Popma et al. (22\%) and this study (8.2\%) is most likely related to the difference in definitions used [29]. In the former, recoil was defined as the difference between the mean final balloon diameter and the minimal luminal diameter post stent implantation, while in this study recoil was defined as the difference in the mean final balloon diameter and the mean diameter of the stented segment. This definition was chosen because we were interested in the behavior of the vessel wall of the entire stented segment. Studies using either quantitative coronary angiography or a combination of a balloon catheter that houses a ultrasound transducer clearly demonstrated that balloon expansion is not uniform $[11,16]$. This has recently been observed in balloons on which a stent was mounted resulting in asymmetric stent expansion [31]. This finding suggests that one part of the dilated or stented segment may yield more easily to the mechanical force of the balloon than the other. Therefore, one seg- 
TABLE III. Relationship Between Clinical and Angiographic Variables and Acute Recoil: Results of Univariate Analysis*

\begin{tabular}{|c|c|c|c|c|}
\hline & $\mathrm{n}$ & $\begin{array}{l}\text { Acute recoil } \\
\qquad(\mathrm{mm})\end{array}$ & Difference & $95 \% \mathrm{CI}$ \\
\hline \multicolumn{5}{|l|}{ Sex } \\
\hline Male & 68 & $0.29 \pm 0.32$ & - & - \\
\hline Female & 9 & $-0.01 \pm 0.21$ & 0.30 & $(0.08 ; 0.51)$ \\
\hline \multicolumn{5}{|c|}{ Reference diameter $(\mathrm{mm})^{\mathbf{a}}$} \\
\hline$<2.5$ & 23 & $0.36 \pm 0.30$ & - & - \\
\hline $2.5-3.0$ & 26 & $0.25 \pm 0.28$ & 0.11 & $(-0.05 ; 0.28)$ \\
\hline$\geq 3.0$ & 26 & $0.15 \pm 0.35$ & 0.21 & $(0.03 ; 0.40)$ \\
\hline \multicolumn{5}{|c|}{ Lesion length (mm) ${ }^{a}$} \\
\hline$<11.5$ & 25 & $0.35 \pm 0.22$ & - & - \\
\hline $11.5-13.5$ & 25 & $0.19 \pm 0.23$ & 0.16 & $(0.04 ; 0.29)$ \\
\hline$\geq 13.5$ & 25 & $0.21 \pm 0.45$ & 0.14 & $(-0.05 ; 0.34)$ \\
\hline \multicolumn{5}{|c|}{ Stent/artery ratio ${ }^{a}$} \\
\hline$<1.00$ & 23 & $0.07 \pm 0.27$ & - & \\
\hline $1.00-1.13$ & 25 & $0.24 \pm 0.21$ & -0.17 & $(-0.31 ; 0.03)$ \\
\hline$\geq 1.13$ & 27 & $0.43 \pm 0.36$ & -0.36 & $(-0.51 ;-0.12)$ \\
\hline
\end{tabular}

*All parameters are expressed as mean $\pm \mathrm{SD}$.

${ }^{a}$ Of 2 patients, the reference diameter, lesion length, and stent/artery ratio were not known.

TABLE IV. "Late Recoil" Following Wiktor Stent Implantation in Native Coronary Arteries*

\begin{tabular}{lccc}
$\begin{array}{l}\text { Mean stent } \\
\text { diameter } \\
\text { immediately } \\
\text { after implantation }\end{array}$ & $\begin{array}{l}\text { Mean stent } \\
\text { diameter at } \\
\text { follow-up }\end{array}$ & Difference & 95\% Cl \\
\hline $2.99 \pm 0.41 \mathrm{~mm}$ & $3.13 \pm 0.37 \mathrm{~mm}$ & $-0.15 \pm 0.33 \mathrm{~mm}$ & $-0.23 ;-0.07$
\end{tabular}

*All variables are expressed as mean $\pm \mathrm{SD}$; $\mathrm{Cl}$, confidence interval.

ment may experience more stretch than the other, producing more recoil $[11,16,31]$. It is noteworthy that, if we would use the definitions proposed by other investigators to define recoil, it would amount to $0.65 \pm 0.30$ $\mathrm{mm}$ or $21 \%$, which is strikingly similar to the degree of recoil after Wiktor stent implantation reported by Popma et al. [29].

In accordance with data on balloon angioplasty, stent oversizing was found to be the strongest independent predictor of acute recoil after Wiktor stent implantation $[12,13,15]$. Such a relationship was also found by Leon et al. [28] in patients who received a Palmaz-Schatz stent, but it is at variance with the data reported by Haude et al. [30]. The discrepancy between the reported results herein and those of Leon et al., on one hand, and the results of Haude et al. on the other, is unclear. It may be related to differences in matching the stent size to the vessel size. In this study, most patients $(52 \%)$ received a stent that was larger than the target vessel. The mean stent/artery ratio was $1.08 \pm 0.15$ (median 1.0 , range $0.5-1.5$ ). Haude et al. reported a mean stent/artery ratio of 0.96 [30]. Another explanation may be the fact that the degree of recoil observed by Haude et al. was too small to detect such a relationship. Haude and co-workers reported a mean elastic recoil of $0.10 \pm 0.07 \mathrm{~mm}$ $(3.5 \%)$ in diameter and of $0.38 \pm 0.36 \mathrm{~mm}^{2}$ in crosssectional area (5.1\%) after stenting [30].

In this study, female gender was found to predict acute recoil and contrasts with data on balloon angioplasty [12]. One should realize that this conclusion, although statistically significant, was based on data for only nine female patients. Its biological significance is unclear. It is unlikely that the response of the coronary artery to mechanical energy is different between males and females.

Another interesting observation is that there was no late compression of the Wiktor stent itself at follow-up. On the contrary, overall there was an negative "late recoil." Although the principle of balloon-expandable stent implantation is based on the plastic deformation of the stent beyond its elastic properties, it can be speculated that chronic damage to the vessel wall, as observed after Wiktor stent implantation in porcine coronary arteries, may offset opposing forces of the vessel wall permitting further stent expansion [32]. Whether this damage is due to movement of the rigid implant within the vessel wall or to local weakening of the media beneath the stent wires reflecting reparative processes remains to be elucidated. Moreover, methodological reasons, such as changes in projections, contour detection inhomogeneity, and reproducibility of the Cardiovascular Angiography Analysis System (CAAS) system, may contribute to and explain this observation.

The absence of late recoil, in addition to the evidence that acute recoil does not contribute to late luminal renarrowing or restenosis (Table V), indicates that late loss 
TABLE V. Relationship Between Acute Recoil (mm) and Late Restenosis*

\begin{tabular}{|c|c|c|c|c|c|c|}
\hline & \multicolumn{6}{|c|}{ Restenosis criterion } \\
\hline & \multicolumn{3}{|c|}{$0.72 \mathrm{~mm}$} & \multicolumn{3}{|c|}{$50 \%$ Diameter stenosis } \\
\hline & $\begin{array}{c}\text { Yes } \\
(\mathrm{n}=33)\end{array}$ & $\begin{array}{c}\text { No } \\
(n=44)\end{array}$ & Difference & $\begin{array}{c}\text { Yes } \\
(\mathrm{n}=21) \\
\end{array}$ & $\begin{array}{c}\text { No } \\
(\mathrm{n}=54)\end{array}$ & Difference \\
\hline $\begin{array}{l}\text { Acute recoil } 1 \\
95 \% \mathrm{Cl}\end{array}$ & $\begin{array}{c}0.26 \pm 0.26 \\
(0.13 ; 0.39)\end{array}$ & $\begin{array}{l}0.25 \pm 0.29 \\
(0.16 ; 0.34)\end{array}$ & $\begin{array}{l}-0.02 \pm 0.30 \\
(-0.14 ; 0.16)\end{array}$ & $\begin{array}{l}0.28 \pm 0.42 \\
(0.09 ; 0.47)\end{array}$ & $\begin{array}{l}0.24 \pm 0.28 \\
(0.16 ; 0.31)\end{array}$ & $\begin{array}{r}0.04 \pm 0.32 \\
(-0.12 ; 0.21)\end{array}$ \\
\hline $\begin{array}{c}\text { Acute recoil } 2 \\
95 \% \mathrm{CI} \\
\end{array}$ & $\begin{array}{l}0.58 \pm 0.27 \\
(0.48 ; 0.67) \\
\end{array}$ & $\begin{array}{l}0.70 \pm 0.30 \\
(0.61 ; 0.79)\end{array}$ & $\begin{array}{l}-0.12 \pm 0.29 \\
(-0.25 ; 0.01)\end{array}$ & $\begin{array}{l}0.63 \pm 0.28 \\
(0.51 ; 0.76)\end{array}$ & $\begin{array}{l}0.64 \pm 0.31 \\
(0.56 ; 0.73)\end{array}$ & $\begin{array}{l}-0.01 \pm 0.30 \\
(-0.16 ; 0.14)\end{array}$ \\
\hline
\end{tabular}

*All values are expressed as mean $\pm \mathrm{SD}$. Acute recoil 1, difference between mean final balloon diameter and mean diameter stented segment: acute recoil 2 , difference between mean final balloon diameter and minimal luminal diameter post-stent implantation; $\mathrm{CI}$, confidence interval.

in minimal luminal diameter is due to tissue ingrowth into the lumen of the stented segment. This is in accordance with pathologic observations disclosing that the predominant cause of restenosis following balloon angioplasty or stent implantation is extensive neointimal thickening due to smooth muscle cell proliferation at the dilated or stented site $[27,32,33-37]$.

\section{Contrast Angiography to Assess Recoil}

Elastic recoil implies an active component of the vessel wall which, for obvious reasons, cannot be directly studied with contrast angiography. This technique, which was used in almost all other studies on recoil after balloon angioplasty and intracoronary stenting, at best describes the luminal changes but does not provide any insight into the underlying pathological mechanisms [12-16,26-28]. In addition to recoil, other mechanisms, such as vasoconstriction, platelet deposition, nonocclusive mural thrombus formation, and subintimal hemorrhage, have been proposed to cause early luminal narrowing [12]. Although attractive from a theoretical point of view, these mechanisms are unlikely to explain these changes. Vasomotion was controlled by intracoronary injection of nitrates before each cine run which effectively reverses vasoconstriction [24]. Given the intrinsic thrombogenicity of the intracoronary stent, platelet deposition and mural thrombus formation cannot be ruled out. Nevertheless, it is unlikely to be the cause of the reduced luminal diameter, taking into account the time interval between stent implantation and control angiography. The same holds for intramural hemorrhage. Stents have been shown to prevent vessel collapse effectively in such circumstances [38].

Obviously, the ideal method to study the nature of vessel wall behaviour during coronary intervention is the use of intravascular ultrasound and preferably the use of a combination of a balloon-ultrasound imaging catheter described by Isner et al. [11]. This method offers the unique opportunity to assess vessel wall changes continuously before, after, and above all during balloon infla- tion. The preliminary results reported by Görge et al. [39], who used conventional intravascular ultrasound techniques, suggests that recoil indeed exists after stent implantation.

\section{Automated Edge Detection to Quantify Recoil}

To quantify recoil, one has to rely on cardiac imaging techniques with known precision, accuracy, and interand intraobserver variability. The computer-assisted CAAS used in this study has been extensively validated in both the clinical as well as in the experimental setting following balloon angioplasty and stent implantation [40-45]. Despite the radiopacity of the Wiktor stent, it is our experience that in case of adequate filling of the balloon or coronary artery with contrast medium at a concentration of $100 \%$, the radiopaque stent wires do not interfere with the automated contour detection $[19,22,43]$. This is explained by the high iodine content in the coronary artery in such circumstances, which absorbs most of the incoming X-rays. This is also in accordance with phantom studies from our laboratory, which disclosed that automated contour detection, in contrast to videodensitometry, adequately identified luminal contours of a Wiktor stent-containing plexiglass phantom [43]. With respect to intravascular ultrasound, it should be acknowledged that, notwithstanding its value and importance, the delineation of the arterial boundaries is subjective and therefore may not always be precise.

\section{CONCLUSIONS}

The Wiktor stent effectively scaffolds the instrumented vessel. Although statistically significant, only a minimal amount of acute recoil was noted, which did not contribute to late luminal renarrowing or restenosis. In addition, no late compression of the stent itself was observed. Therefore, tissue ingrowth into the lumen of the stented segment is the main cause of late luminal renarrowing after stent implantation. 


\section{ACKNOWLEDGMENTS}

The authors greatly acknowledged Marie-Angèle Morel for performing the quantitative analysis and for her assistance in the database management and statistical analysis. We are indebted to Dr. David Kean for his review of the manuscript.

\section{REFERENCES}

1. Losordo DW, Rosenfield K, Pieczek A, Baker K, Harding M, Isner JM: How does angioplasty work? Serial analysis of human iliac arteries using intravascular ultrasound. Circulation 86:18451858, 1992.

2. Block PC, Baughman KL, Pasternak PR, Fallon JT: Transluminal angioplasty: Correlation of morphologic and angiographic findings in experimental model. Circulation 61:778-785, 1980.

3. Sanborn TA, Faxon DP, Waugh D, et al.: Transluminal angioplasty in experimental atherosclerosis. Analysis for embolization using an in vivo perfusion system. Circulation 66:917-922, 1982.

4. Sanborn TA, Faxon DP, Haudenschild C, Gottsman SB, Ryan TJ: The mechanisms of transluminal angioplasty: Evidence for formation of aneurysms in experimental atherosclerosis. Circulation 68:1136-1140, 1983

5. Lee G, Ikeda R, Joye J, Bognen H, DeMaria A, Mason D: Evaluation of transluminal angioplasty of chronic coronary artery stenosis: Value and limitations assessed in fresh human cadaver hearts. Circulation 61:77-83, 1980.

6. Waller BF, McManus BM, Gorfinkel HJ, et al.: Status of the major coronary arteries 80 to 150 days after percutaneous transluminal coronary angioplasty: Analysis of 3 necropsy patients. Am J Cardiol 51:81-84, 1983.

7. Waller BF: Early and late morphologic changes in human coronary arteries after percutaneous transluminal coronary angioplasty. Clin Cardiol 6:363-372, 1983.

8. The SHK, Gussenhoven EJ, Zhong Y, et al.: Effect of balloon angioplasty on femoral artery evaluated with intravascular ultrasound imaging. Circulation 86:483-493, 1992.

9. Potkin BN, Keren G, Mintz GS, et al.: Arterial responses to balloon coronary angioplasty: An intravascular ultrasound study. J Am Coll Cardiol 20:942-951, 1992.

10. Hodgson J, Reddy KG, Suneja R, et al.: Intracoronary ultrasound imaging: correlation of plaque morphology with angiography, clinical syndorme and procedural results in patients undergoing coronary angioplasty. J Am Coll Cardiol 21:35-44, 1993.

11. Isner JM, Rosenfield K, Losordo DW, et al.: Combination balloon-ultrasound imaging catheter for percutaneous transluminal angioplasty. Validation of imaging, analysis of recoil, and identification of plaque fracture. Circulation 84:739-745, 1991.

12. Rensing BJ, Hermans WRM, Beatt KJ, et al.: Quantitative angiographic assessment of elastic recoil after percutaneous transluminal coronary angioplasty. Am J Cardiol 66:1039-1044, 1990.

13. Hjemdahl-Monsen CE, Ambrose JA, Borrico S, et al.: Angiographic patterns of balloon inflation during percutaneous transluminal coronary angioplasty: Role of pressure-diameter curves in studying distensibility and elasticity of the stenotic lesion and the mechanism of dilation. J Am Coll Cardiol 16:569-575, 1990.

14. Rensing BJ, Hermans WR, Strauss BH, Serruys PW: Regional differences in elastic recoil after percutaneous transluminal coronary angioplasty: A quantitative angiographic study. J Am Coll Cardiol 17:34B-38B, 1992.

15. Hanet C, Wijns W, Michel X, Schroeder E: Influence of balloon size and stenosis morphology on immediate and delayed elastic recoil after percutaneous transluminal coronary angioplasty. J Am Coll Cardiol 18:506-511, 1991.

16. Hermans WRM, Rensing BJ, Strauss BH, Serruys PW: Methodological problems related to the quantitative assessment of stretch, elastic recoil, and balloon-artery ratio. Cathet Cardiovasc Diagn 25:174-185, 1992.

17. Sigwart U, Puel J, Mirkovitch V, Joffre F, Kappenberger $\mathbf{L}$ Intravascular stents to prevent occlusion and restenosis after transluminal angioplasty. N Engl J Med 316:701-706, 1987.

18. Schatz RA, Baim DS, Leon $M$, et al.: Clinical experience with the Palmaz-Schatz coronary stent. Initial results of a multicenter study. Circulation 83:148-161, 1991.

19. de Jaegere PP, Serruys PW, Bertrand M, et al.: Wiktor stent implantation in patients with restenosis following balloon angioplasty of a native coronary artery. Am J Cardiol 69:598-602, 1992.

20. Roubin GS, Cannon AD, Agrawal SK, et al.: Intracoronary stenting for acute and threatened closure complicating percutaneous transluminal coronary angioplasty. Circulation 85:916-927, 1992.

21. Reifart N, Langer A, Störger H, Schwarz F, Preusler W, Hofmann M: Strecker stent as a bailout device following percutaneous transluminal coronary angioplasty. J Interven Cardiol 5:79 83, 1992.

22. Serruys PW, de Jaegere $P$, Bertrand $M$, et al.: Morphologic change in coronary artery stenosis with the Medtronic Wiktor stent: Initial results from the core laboratory for quantitative angiography. Cathet Cardiovasc Diagn. 24:237-245, 1991

23. Reiber JHC: An overview of coronary quantitation techniques as of 1989. In Reiber JHC, Serruys PW (eds): Quantitative Coronary Angiography. Dordrecht: Kluwer Academic Publishers, 1991, pp 55-132.

24. Fischell TA, Derby G, Tse TM, Stadius ML: Coronary artery vasoconstriction routinely occurs after percutaneous transluminal coronary angioplasty. A quantitative arteriographic analysis. Circulation 78:1323-1334, 1988.

25. Gardner MJ, Altman DG: Statistics with confidence. Br Med J 299:690, 1989.

26. Rothman KJ: Multivariate analysis. In Rothman (eds): Modern Epidemiology. Boston, Little Brown, 1986, pp 285-310.

27. van der Giessen WJ, Serruys PW, van Beusekom HMM: Coronary stenting with a new, radiopaque, balloon-expandable endoprosthesis in pigs. Circulation 83:1788-1798, 1991.

28. Leon MB, Popma JF, Fischman DL, et al.: Vascular recoil immediately after implantation of tubular slotted metallic coronary stents. J Am Coll Cardiol 19:109A, 1992.

29. Popma JJ, White Ch, Pinkerton CA, Ramee S, Keller MB, Leon MB: Effect of balloon expandable stent design on vascular recoil and lesion-site morphology after intracoronary placement. Circulation 86:1321A, 1992.

30. Haude $M$, Erbel R, Issa H, Meyer J: Quantitative analysis of elastic recoil after balloon angioplasty and after intracoronary implantation of balloon-expandable Palmaz-Schatz stents. J Am Coll Cardiol 21:26-34, 1993.

31. Zeiher AM, Hohnloser S, Fassbender S, Wollschlager H, Just H: Intracoronary ultrasound morphology following interventional therapy in coronary artery disease. Eur Heart J 13:1690A, 1992.

32. van Buesekom HMM, van der Giessen WJ, van Suylen RJ, et al.: Histology after stenting of human vein grafts: observations from surgically excised grafts 3 to 320 days after stent implantation. J Am Coll Cardiol 21:45-54, 1993.

33. Essed CE, van den Brand M, Becker AE: Transluminal coronary angioplasty and early restenosis. Fibrocellular occlusion after wall laceration. Br Heart J 49:393-396, 1983. 
34. Austin GE, Ratliff NR, Hollman J, Tabei S, Phillips DF: Intimal proliferation of smooth muscle cells as an explanation for recurrent coronary artery stenosis after percutaneous transluminal coronary angioplasty. J Am Coll Cardiol 6:369-375, 1985.

35. Nobuyoshi M, Kimura $\mathrm{T}$, Ohishi $\mathrm{H}$, et al.: Restenosis after percutaneous transluminal coronary angioplasty: Pathologic observations in 20 patients. J Am Coll Cardiol 17:433-439, 1991.

36. White CJ, Ramee SR, Banks AK, Mesa JE, Chokshi S, Isner JM: A new balloon-expandable tantalum coil stent: Angiographic patency and histologic findings in an atherogenic swine model. J Am Coll Cardiol 19:864-968, 1992.

37. Schwartz RS, Huber KC, Murphy JG, et al.: Restenosis and the proportional neointimal response to coronary artery injury: resuits in a porcine model. J Am Coll Cardiol 19:267-274, 1992.

38. Schatz RA: A view of vascular stents. Circulation 79:445-457, 1988.

39. Görge G, Erbel R, Ge J, Gerber T. Haude M, Meyer J: Intravascular ultrasound after stent implantation: can stent recoil or compression occur? Eur Heart J 13:1690A, 1992.

40. Reiber JHC, Serruys PW, Kooijman CJ, et al:: Assessment of short-, medium-, and long-term variations in arterial dimensions from computer-assisted quantitation of coronary cineangiograms. Circulation 71:280-288, 1985.

41. Serruys PW, Juilliere Y, Bertrand ME, Puel J, Rickards AF, Sigwart U: Additional improvement of stenosis geometry in human coronary arteries by stenting after balloon dilatation. Am J Cardiol 61:7IG-76G, 1988.

42. Strauss BH, Juilliere Y, Rensing BJ, Reiber JHC, Sertuys PW: Edge detection versus densitometry for assessing coronary stenting quantiatively. Am J Cardiol 67:484-490, 1991.

43. Strauss BH, Rensing BJ, den Boer A, van der Giessen WJ, Reiber JHC, Sernuys PW: Do stents interfere with the densitometric assessment of a coronary artery lesion? Cathet Cardiovasc Diagn 24:259-264, 1991

44. di Mario C, Haase J, den Boer A, Reiber JHC, Serruys PW: Edge detection versus videodensitometry in the quantitative assessment of stenosis phantoms: An in vivo comparison in porcine coronary arteries. Am Heant J 124:1181-1189, 1992.

45. Haase J, di Mario C, Slager CJ, et al.: In-vivo validation of on-line and off-line geometric coronary measurements using insertion of stenosis phantoms in porcine coronary arteries. Cathet Cardiovasc Diagn 27:16-27, 1992. 